\title{
Elevers formande av arbetsplatsförlagt lärande i svensk gymnasial lärlingsutbildning
}

\author{
How students in Swedish upper secondary apprenticeship education \\ contribute to form their education in relation to work-based learning
}

\section{Ingela Andersson}

\author{
Göteborgs universitet, Sverige (ingela.andersson@gu.se) \\ Viveca Lindberg \\ Stockholms universitet, Sverige
}

\begin{abstract}
The article examines how students in Swedish upper secondary apprenticeship education contribute to the shaping of their education through their choices and actions in relation to work-based learning. Activity theory and the notion of interacting activity systems was used to emphasise the students' perspective as active subjects. Data was collected through observations and interviews with 15 students in their second year of an apprenticeship. An initial qualitative content analysis revealed a pattern of actions that related to both school and work. The result of this analysis was further elaborated with activity theoretical concepts. Thereby dominating rules/norms and tools they made use of, contributed to identifying three potential objects for students' actions: grades in vocational subjects, development of vocational skills, and inclusion in the workplace community. Depending on what objects the students held as superior and subordinate different outcomes could be achieved - an upper secondary vocational degree, development of vocational skills, and/or being employed while studying. One object did not necessarily exclude the others. It is concluded that the multiple expectations from students, school, and workplaces that coexist in relation to work-based learning need to be continuously communicated among all participants to strengthen the students' possibility to achieve their desired educational outcome.
\end{abstract}

Keywords: activity theory, qualitative content analysis, student perspective, upper secondary apprenticeship education, work-based learning 


\title{
Introduktion
}

Skolförlagd gymnasial yrkesutbildning har dominerat i Sverige sedan 1970 då den sammanhållna gymnasieskolan infördes. Sedan början av 2000-talet har emellertid lärlingsformen, som ett alternativ inom gymnasieskolan, kommit att betonas allt mer. Å ena sidan ses lärlingsformen som ett alternativ för ungdomar som inte lyckas i skolförlagd utbildning, å andra sidan som ett svar på arbetslivets krav på kunniga medarbetare (Andersson m.fl., 2015; Bäckman, m.fl., 2011; Lundahl m.fl., 2010; Olofsson \& Persson Thunqvist, 2018). I den sammanhållna gymnasieskolan betonas dessutom elevernas valfrihet och inflytande, med motiveringen att de ska ha möjlighet att bidra till att utforma sin individuella kompetens. Av Lgy70 (Skolöverstyrelsen, 1971, s. 18) framgår att:

\begin{abstract}
... individens behov och samhällets krav i olika avseenden är bestämmande för innehållet, formerna och organisationen av skolans verksamhet. Skolan skall även ge eleverna möjlighet att påverka sina arbetsvillkor. [...] Gymnasieskolans yttre organisation och inre arbete måste därför formas så, att det blir möjligt för varje enskild elev att finna studievägar och arbetssätt som främjar den personliga utvecklingen.
\end{abstract}

Elevernas val i 1970 års läroplan berör dels val mellan yrkesgrenarna, dels val av ett allmänt ämne (matematik, engelska eller bild) utöver svenska och idrott. 1990talets reformering av gymnasieskolan medför att eleverna får utökade valmöjligheter. Det individuella valet omfattar minst 190 gymnasiepoäng och ger varje elev möjlighet att välja kurser enligt den lokala skolans utbud (Prop. 1990/91:85; SOU 1997:107). Sedan 2011 kan ungdomar mellan 16 och 19 år också välja mellan att genomföra sin treåriga gymnasiala yrkesutbildning i skolbaserad form eller i lärlingsform. Elever som väljer lärlingsformen genomför minst hälften av utbildningen som arbetsplatsförlagt lärande (apl). Elever som väljer motsvarande yrkesutbildning i skolförlagd form genomför minst 15 veckor apl som fördelas över utbildningens tre år (SFS 2010:800).

Det finns ett fåtal svenska studier som har undersökt betydelsen av de val elever i gymnasial yrkesutbildning utför (Lund, 2006; Rosvall, 2012). Lund (2006) visar att eleverna gör sina egna val på olika grunder. Valet av till exempel gymnasieprogram baseras på egna intressen, kamraters val samt de yrken som förekommer i familjen. Rosvall (2012) visar i likhet med Lund (2006) att eleverna väljer kurser och genomför skoluppgifter utifrån sina egna föreställningar om sin utbildning. Genom sina val och handlingar kan eleverna både avgränsa och inrikta sin utbildning mot eftergymnasiala studier eller något yrkesområde som intresserar dem. Studierna belyser således hur eleverna bidrar till att forma sin skolförlagda utbildning genom de valhandlingar (Lund, 2006) de utför inför och under gymnasietiden, samt genom det inflytande (Rosvall, 2012) de kan utöva i skolans undervisning. Hur elever i gymnasial lärlingsutbildning bidrar till att forma sin utbildning i samband med apl har inte undersökts. 
Både studier som genomförts i försöksverksamhet med gymnasial lärlingsutbildning (2008-2011) och i den lärlingsform som infördes 2011 (Berglund m.fl., 2016; Berglund m.fl., 2017) visar på liknande problem när stora delar av utbildningen genomförs på arbetsplatser: De arbetsuppgifter eleverna får utföra stämmer inte nödvändigtvis överens med deras föreställningar om vad de ska lära sig på arbetsplatsen. Kristmansson (2016) visar exempelvis att enkla rutinuppgifter kan dominera för elever på handels- och administrationsprogrammet. Det kan dessutom vara svårt att få tillgång till mer avancerade uppgifter. Även i vårdoch omsorgsutbildningen förekommer det skillnader mellan vilka arbetsuppgifter eleverna får utföra på sina arbetsplatser, trots att samma arbetsuppgifter förekommer på alla arbetsplatser (Paul, 2017). Baserat på den här typen av resultat framträder en spänning (Engeström \& Saninno, 2011) där de skolbaserade läroplanerna, som sedan länge har framhållit elevernas intresse och möjlighet att påverka utbildningen (Forsberg, 2011), ställs mot de begränsade möjligheter att utföra olika uppgifter som förekommer på arbetsplatserna. För eleverna handlar den gymnasiala lärlingsutbildningen om både skola och arbete när arbetsplatsen blir skola. Syftet med den här artikeln är att undersöka hur elever i svensk gymnasial lärlingsutbildning, genom sina val och handlingar, bidrar till att forma sin yrkesutbildning i förhållande till den del som genomförs som apl på arbetsplatser.

Artikeln är disponerad enligt följande: Först följer en litteraturgenomgång. Därefter redovisas studiens verksamhetsteoretiska utgångspunkter. Syfte och frågeställningar preciseras i relation till detta perspektiv. Metodavsnittet beskriver genomförandet av fallstudien vid en gymnasieskola, samt principerna för hur data analyserats, först med kvalitativ innehållsanalys, sedan med verksamhetsteoretiska begrepp. Analysen visar hur eleverna är med och formar sin utbildning inom och mellan skolan och arbetsplatsen och vad som framstår som deras möjliga objekt (syften) för utbildningen.

\section{Tidigare forskning}

Alltsedan tidigt 1990-tal har forskningsintresset för lärlingsformen för yrkesutbildning ökat (Billett, 2016; Fuller \& Unwin, 2011). Det är dock först på 2000-talet som forskningsintresset för elevers perspektiv i yrkesutbildningen växer fram. Schaap m.fl. (2012) har i sin översikt granskat forskning om vad elever försöker åstadkomma i yrkesutbildningen. Översikten visar att vanliga forskningsintressen är elevers kunskapsutveckling, integrering av vad de lär sig i skolan och på arbetsplatser, motivation, lärstilar, utveckling av yrkeskunnande, samt utveckling av yrkesidentitet. Vad som motiverar elever till att lära sig ett yrke förklaras som kontextberoende i förhållande till individuella förutsättningar och vad som möjliggörs i yrkesutbildningens lärmiljöer, skolan och arbetsplatsen. Forsknings- 
genomgången i den här artikeln fokuserar på elevers perspektiv på yrkesutbildning och bygger således vidare på översikten av Schaap m.fl. (2012). Genomgången innefattar artiklar publicerade efter 2009 liksom svenska doktors- och licentiatavhandlingar. I det följande redovisas forskning om i) elevers sammanlänkning av olika lärmiljöer, ii) elevers kommunikation om lärande på arbetsplatser, samt iii) elevers agens och utveckling av yrkeskunnande.

\section{Elevers sammanlänkning av yrkesutbildningens olika lärmiljöer}

Studier om olika länders utbildningsmodeller visar att sammanlänkade lärmiljöer är betydelsefulla för elever i yrkesutbildning. Sammanlänkning handlar exempelvis om att eleverna utför arbetsuppgifter i skolans övningslokaler, eller om andra sätt att relatera undervisningen till yrkesutövandet (Berglund, 2009; Berner, 2010). Elevers sammanlänkning av skola och arbete är framträdande i studier som undersöker elevers upplevelser och erfarenheter av kunskapsintegration och lärprocesser (Baartman m.fl., 2018), transfer (Kilbrink m.fl., 2018), koherens (Aakernes, 2017), gränsdragningar (Jonasson, 2014) och konnektivitet (Sappa \& Aprea, 2014) i sin yrkesutbildning. Connectivity (ex. Griffiths \& Guile, 2003) och boundary crossing (ex. Akkerman \& Bakker, 2012) är exempel på teoretiska begrepp som används för att beskriva hur skola och arbete ansluter till varandra. Begreppen används även för att undersöka hur elever utvecklar kunskaper och färdigheter över gränser mellan verksamhetssystem (Tuomi-Gröhn m.fl., 2003) eller i praktikgemenskaper (Wenger, 1998). Elevers sammanlänkning av erfarenheter från skolan och arbetsplatser undersöks även inom ramen för den antagna läroplanen (Billett m.fl., 2018). Sammanfattningsvis visar dessa studier att skola och arbetsplats utgör skilda lärmiljöer som eleverna ibland kan uppleva som sammanlänkade beroende på hur utbildningen arrangeras.

\section{Elevers kommunikation om lärande på arbetsplatser}

Nielsen m.fl. (2021) visar i en dansk studie att det blir problematiskt när elever och arbetsplatser har olika förväntningar: Medan eleverna huvudsakligen förväntar sig att bemötas som elever som ska lära sig yrket på arbetsplatsen, förväntar sig arbetsplatserna att eleverna ska visa en professionell inställning som framtida medarbetare. För att överbrygga skillnaderna föreslås att elever och arbetsplatsens medarbetare samtalar om förväntningar. Vidare visar en storskalig finsk enkätstudie ( $N=1603$ ) som genomförts av Virtanen m.fl. (2014) att skriftligt formulerade planer för vilka arbetsuppgifter elever ska lära sig att utföra på en arbetsplats kan tydliggöra vilka kunskaper eleverna förväntas utveckla. Skriftlig kommunikation i lärjournaler och portfolios får också ett värde då den, enligt Garmannslund och Witsø (2017), Nore och Lahn (2014), samt Sandal m.fl. (2014) kan visa vad eleven ska lära sig på arbetsplatsen. Även studier om elevers samtal med lärare och handledare visar att samtalen har ett värde då de medför att eleven kan få syn på sin egen utveckling (Mårtensson, 2014; Wyszynska Johansson, 
2021). Sammanfattningsvis visar studierna att elever tillskriver kommunikation om deras kunskapsutveckling på arbetsplatsen stor betydelse.

\section{Elevers agens och utveckling av yrkeskunnande}

Flera studier visar att både elevers interaktion med andra på arbetsplatsen och de arbetsuppgifter de får utföra har betydelse för vilket yrkeskunnande de kan utveckla (Aspøj \& Nyen, 2017; Ferm, 2021; Gåfvels, 2016; Paul, 2017; Sappa m.fl., 2016). Genom att anpassa sig till produktionen får elever tillgång till situationsbaserade kunskaper och färdigheter. Reegård (2020) och Kristmansson (2016) visar att handelselever redan efter en kort tid på arbetsplatsen kan arbeta självständigt, samt att de efterhand får ökat ansvar. Rintala och Nokelainen (2020) visar hur elever i vårdutbildning lär sig yrket genom att följa en utbildningsplan på arbetsplatsen, medan elever i byggutbildning följer arbetsplatsens läroplan. Till skillnad från ovan nämnda studier ger Ferm m.fl. (2018) exempel på hur elever kan påverka vad de lär sig på arbetsplatsen genom att använda olika lärstrategier - de ställer frågor, identifierar förebilder och ställer sig till förfogande för olika arbetsuppgifter. Sammanfattningsvis visar dessa studier hur elever agerar inom ramen för de förutsättningar som ges på olika arbetsplatser.

I korthet visar kunskapsöversikten att studier som utgår från elevernas perspektiv framför allt ger en inblick i hur elever i olika yrkesutbildningar upplever utbildningsvägar som skapats av andra aktörer. I studien som redovisas i den här artikeln riktas intresset i stället mot hur elever bidrar till att forma sin egen utbildning i samband med arbetsplatsförlagt lärande.

\section{Studiens verksamhetsteoretiska utgångspunkter}

I den här artikeln förstås och förklaras elevernas formande av sin utbildning som objektsorienterad verksamhet (Engeström, 2001). Verksamhetssystem och dess objekt är inte statiska fenomen som finns i vår omgivning utan en analytisk väg för att förstå och förklara ett sammanhang där människor, genom sina handlingar, är med och transformerar de verksamhetssystem de ingår i (Stetsenko, 2005). Det betyder att yrkesutbildning som verksamhetssystem förändras över tid genom deltagarnas handlingar. Även eleverna ingår som deltagare i yrkesutbildningen. Vad som utgör elevernas objekt är inte givet och huruvida det sammanfaller med övriga deltagares objekt är en empirisk fråga: "An object is held by the subject and motivates activity, giving it a specific direction" (Nardi, 1996, s. 73). För att identifiera potentiella objekt behöver deltagarnas handlingar analyseras. En verksamhetsteoretisk analys genomförs ofta med stöd i Engeströms (2001, s. 135) triangelformade modell av ett verksamhetssystem och dess samverkande noder, subjekt, redskap, objekt, regler, gemenskap och arbetsdelning (se figur 1). Objektet framställs som en cirkel för att visa att objektsorienterad verksamhet är flertydig och föremål för deltagarnas tolkningar, samtidigt som den tar 
form i förhållande till flera, ibland motstridiga, samhälleliga motiv. Dubbelriktade pilar visar att noderna i verksamhetssystemet står i relation till varandra. Genom att analysera handlingsmönster som manifesteras i ett pågående verksamhetssystem blir det möjligt att identifiera objekt som flera handlingar riktas mot, och som deltagarna kan ha för avsikt att transformera till ett resultat på den lokala handlingsnivån.

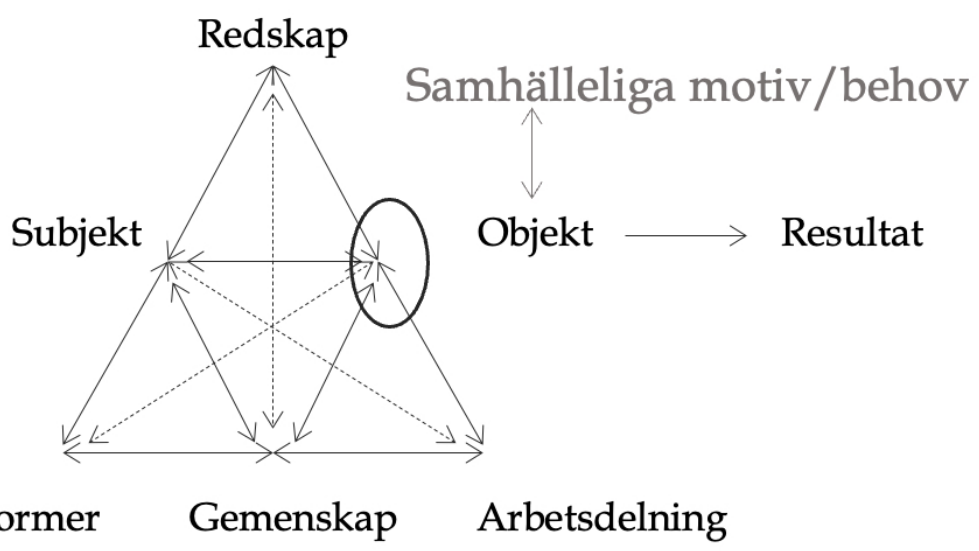

Figur 1. Verksamhetssystem som analysmodell (efter Engeström, 2001, s. 135).

Tidigare verksamhetsteoretiska studier som undersökt elevers lärande och utveckling av yrkeskunnande använder teorin för att särskilja skolan och arbetsplatsen som lärmiljöer med olika objekt (Berglund, 2009; Fjellström 2017; Kristmansson, 2016). För lärarna utgör elevernas lärande verksamhetssystemets huvudsakliga objekt - det som står i förgrunden, medan varor och tjänster som produceras i skolverkstäder utgör ett biresultat. För arbetsplatserna utgör i stället produktionen av varor och tjänster verksamhetssystemets huvudsakliga objekt, medan personalens (inklusive elevernas) lärande är ofrånkomligt men ett biresultat. När elever utbildas på arbetsplatser interagerar skolan och arbetsplatsen och elevernas lärande kan i bästa fall bli ett delat objekt (Andersson, 2018). Vi väljer att betrakta skolan och elevernas arbetsplatser, där de genomför sin yrkesutbildning, som interagerande verksamhetssystem.

I likhet med andra studier med begränsade data (en termin, se nedan) avgränsas analysen till de data som svarar mot några centrala verksamhetsteoretiska begrepp (jmf. Miettinen, 1999). Centralt för vår analys är redskap som eleverna kan ta i bruk i förhållande till apl, för att realisera det vi identifierat som objekt, samt vilket/vilka resultat objekten därmed transformeras till. Hur eleverna handlar i förhållande till dominerande regler och normer analyseras för att förklara hur de genom sina val och handlingar är med och formar sin utbildning $i$ de gemenskaper de ingår i, inom ramen för rådande arbetsdelning. Eleverna stöter också på problem eller störningar - något som inte fungerar som det ska. I 
verksamhetsteoretisk mening är dessa vardagliga problem och störningar manifestationer av historiskt ackumulerade spänningar och motsättningar, som finns inom och mellan verksamhetssystem (i detta fall skola och arbetsplats), samt mellan verksamhetssystemets (yrkesutbildningens) tidigare, samtida och möjliga framtida form (Engeström \& Sannino, 2011). Genom att i analysen inkludera hur eleverna hanterar manifestationer av spänningar och motsättningar får vi ledtrådar till elevernas möjliga objekt - vad de avser att åstadkomma med sin pågående yrkesutbildning.

Medan flera studier beskriver yrkesutbildningen utifrån det som framstår som yrkeslärarnas objekt (jmf. Lindberg, 2003) är en poäng med elevperspektivet, som vi valt att utgå ifrån, att inte enbart se eleverna som föremål för lärarnas handlingar utan som aktiva subjekt. Eleverna delar inte nödvändigtvis verksamhetssystemets objekt, men så länge de inte avbryter sin utbildning utgår vi från att det objekt som deras handlingar riktas mot kan realiseras inom ramen för utbildningen. Eleverna använder således utbildningen för att transformera denna till ett resultat, vilket betyder att yrkesutbildningens potentiella objekt också kan ha ett bruks- och bytesvärde (Engeström, 2001) för eleverna.

Det preciserade verksamhetsteoretiskt baserade syftet är att undersöka vad som framstår som lärlingselevernas objekt för yrkesutbildningen, samt att undersöka hur eleverna genom sina val, som är relaterade till apl, bidrar till att realisera objektet. Val i detta sammanhang ses som en handling som får konsekvenser för utbildningens innehåll och elevens kunnande. Följande frågeställningar undersöks: Vilka valhandlingar gör eleverna i relation till apl? Hur bidrar dessa valhandlingar till att forma deras apl? Vilket yrkeskunnande kan eleverna därigenom få tillgång till?

\section{Metod}

Fallstudien genomfördes 2014 med 15 elever som gick andra året av sin lärlingsutbildning vid en västsvensk gymnasieskola. Urvalet baserades på att de flesta elever i årskurs två hade kommit så långt i sin utbildning att de valt vilket yrke de skulle utbilda sig till. Den aktuella skolan organiserade yrkesutbildning i lärlingsform för $6 \%$ av de elever som hade valt något av följande yrkesprogram: Barn- och fritidsprogrammet, Handels- och administrationsprogrammet, Hotelloch turismprogrammet, Restaurang- och livsmedelsprogrammet, samt Vård- och omsorgsprogrammet. Lärlingseleverna tillbringade tre dagar per vecka på sina arbetsplatser och två dagar i skolan, där de hade undervisning enligt skolans schema. De kunde välja att utbilda sig på arbetsplatser som de själva och skolan ingått avtal med. Eleverna valde sina arbetsplatser i samråd med sina respektive yrkeslärare och skolans lärlingskoordinator, som var den person som hade huvudansvaret för att administrera arbetsplatsplaceringarna. 
Flera metoder har använts för att producera och analysera data (Yin, 2018). Data har samlats in, under en termin, genom elevintervjuer och observationer i den aktuella skolan och vid arbetsplatsbesök. Författare 1 följde eleverna under fem skoldagar (8.00-17.00) när de hade undervisning i allmänna ämnen och yrkesteori. Under rasterna placerade författare 1 sig i lärlingskoordinators arbetsrum, dit eleverna kom med frågor om sina arbetsplatsplaceringar. Författare 1 följde också med en yrkeslärare vid fyra arbetsplatsbesök för att observera trepartssamtalet mellan elev, lärare och handledare. Under observationerna fördes fältanteckningar om samtal, handlingar och de dokument som användes för apl. Varje elev intervjuades (15-22 min) i syfte att samla in kompletterande data i form av elevernas egna beskrivningar av apl. Frågorna formulerades utifrån fältanteckningarna: Berätta vad du gör på din arbetsplats? Hur vet du vad du kan lära dig? Hur vet din handledare på arbetsplatsen vad du ska lära dig? Hur vet din yrkeslärare vad du gör på arbetsplatsen? Berätta om när du bytt arbetsplats? Intervjuutskrifter och fältanteckningar utgör de data som analyseras.

Analysen genomfördes i två steg. Inledningsvis valdes 38 textsekvenser med elevernas egna beskrivningar av apl ut för en kvalitativ innehållsanalys (Graneheim \& Lundman, 2004). Innehållsanalysen genomfördes för att identifiera mönster som representerade elevernas valhandlingar. För att få ledtrådar till deras objekt analyserades resultatet av innehållsanalysen med stöd av verksamhetsteoretiska begrepp. Genomförandet av dessa analyser redovisas nedan.

Dataproduktionen och analyserna har genomförts och redovisas i enlighet med Vetenskapsrådets (2011) riktlinjer för god forskningssed som gällde när datainsamlingen genomfördes år 2014. Efter överenskommelse med skolledare informerades koordinator, lärare och handledare om studien och muntligt samtycke erhölls. Inför studien gavs muntlig information till eleverna som grupp. I samband med intervjuerna erhölls skriftligt samtycke. För att säkerställa anonymitet har elevernas namn ersatts med en versal och det yrkesprogram som eleven tillhörde. Pronomenet hen används oavsett kön.

\section{Innehållsanalys - tillvägagångssätt och resultat}

Analysarbetet har vägletts av Graneheim och Lundmans (2004) modell för innehållsanalys och genomfördes i tre steg. I det första steget kondenserades den innehållsliga betydelsen i elevernas beskrivningar till koder. Med kod avses ett kort påstående som fångar den innehållsliga kärnan (se exempel i tabell 1).

För att uttolka koder lästes varje sekvens igenom flera gånger och kärninnebörden kondenserades nära den ursprungliga texten, vilket resulterade i koderna yrkeskurser på arbetsplats, innehåll som hör till kursmål, yrkesteori för arbete, arbetsuppgifter för skolan, lära nytt $i$ arbete och förekommande arbetsuppgifter. Elevernas beskrivningar kunde ibland relatera till två koder. I dessa fall genomlästes intervjuutskrifter och fältanteckningar för att bedöma vilken uttolkning som var rimlig i förhållande till sammanhanget. Till exempel bestämdes uppgifter som eleverna 
Elevers formande av arbetsplatsförlagt lärande i svensk gymnasial lärlingsutbildning

behövde redovisa för sina lärare i skolan som innehåll som hör till kursmål. Uppgifter som eleverna utförde med utgångspunkt $i$ de arbetsuppgifter som vanligen utfördes på arbetsplatsen kodades som förekommande arbetsuppgifter. De senare kunde men behövde inte vara kopplade till skolans kurser.

Tabell 1. Intervjuutdrag med sekvenser om apl som abstraheras genom kondensering till koder.

\begin{tabular}{|c|c|c|}
\hline Sekvens med händelseförlopp & $\begin{array}{l}\text { Kondenserad } \\
\text { betydelse }\end{array}$ & Kod \\
\hline $\begin{array}{l}\text { J (Hotell och Turism): Jag hade ingen } \\
\text { aning om hur mycket detaljer det var } \\
\text { som skulle fixas i ett rum innan jag fak- } \\
\text { tiskt var där och gjorde det själv. Så där } \\
\text { har jag lärt mig jättemycket saker som } \\
\text { man inte tänker på som att vika pappret } \\
\text { i en liten trekant. } \\
\text { Intervjuaren: Varför gör man det? } \\
\text { J (HT): Jag vet faktiskt inte, jag har inte } \\
\text { fått något bra svar på det men jag antar } \\
\text { att det ska vara fint. } \\
\text { Intervjuaren: Jag tänkte att det kanske skulle } \\
\text { vara för att gästen ska veta att här är städat. } \\
\text { J (HT): ja kanske det kan ju va så med. } \\
\text { Det är ingen som har gett mig en } \\
\text { förklaring bara sagt att jag ska göra det. }\end{array}$ & $\begin{array}{l}\text { Beskriver } \\
\text { dagliga rutiner, att } \\
\text { hen lär sig } \\
\text { detaljer } \\
\text { genom att göra } \\
\text { som de gör }\end{array}$ & $\begin{array}{l}\text { Förekommande } \\
\text { arbetsuppgifter }\end{array}$ \\
\hline $\begin{array}{l}\text { J (HT) Serveringskursen till exempel, } \\
\text { alltså gästbemötandet är ju helt annor- } \\
\text { lunda när jag är ute och lär mig att ser- } \\
\text { vera. Det tekniska lär jag ju mig precis } \\
\text { på samma sätt som i skolan, hur man } \\
\text { bär och så där. Men, jag möter ju gäster i } \\
\text { verkliga livet, tar beställningar, serverar } \\
\text { mat och så där. }\end{array}$ & $\begin{array}{l}\text { Kopplar till kurs - } \\
\text { Identifierar vad } \\
\text { hen gör som kurs- } \\
\text { mål - beskriver } \\
\text { arbetsteknik i möte } \\
\text { med gäst }\end{array}$ & $\begin{array}{l}\text { Yrkeskurser på } \\
\text { arbetsplats } \\
\\
\text { Innehåll som } \\
\text { hör till } \\
\text { kursmål/ } \\
\text { Förekommande } \\
\text { arbetsuppgifter }\end{array}$ \\
\hline
\end{tabular}

I steg två jämfördes och kontrasterades koderna för att identifiera mönster i elevernas valhandlingar och för att identifiera vilket yrkeskunnande som relaterade till handlingarna. Mönstren bildade temana apl som skola, apl som arbete och apl som sammanförande av skola och arbete. I tabell 2 redovisas en sammanställning av innehållsanalysen. 
Ingela Andersson \& Viveca Lindberg

Tabell 2. Sammanställning av innehållsanalys med teman och koder som visar mönster $i$ elevernas beskrivningar av apl och vilket yrkeskunnande som framträder.



Det tredje steget bestod i att gå tillbaka till fältanteckningar och intervjuutskrifter för att säkerställa att uttolkningarna av koder och teman var rimliga. 
Innehållsanalysen resulterade i följande teman: Yrkeskurser på arbetsplats och Innehåll som hör till kursmål tematiserades som Apl som skola. Temat omfattar valhandlingar som eleverna riktade mot att genomföra yrkeskurser som ingick i utbildningen på arbetsplatser. Lära nytt i arbete och Förekommande arbetsuppgifter tematiserades som Apl som arbete och omfattar valhandlingar som eleverna utförde med utgångspunkt i det pågående arbetet på arbetsplatsen. Temat Apl som sammanförande av skola och arbete omfattar koderna Yrkesteori för arbete och Arbetsuppgifter för skolan och består av de valhandlingar som eleverna utförde med utgångspunkt i både skola och arbete.

\section{Resultatanalys med verksamhetsteoretiska begrepp}

För att strukturera den verksamhetsteoretiska analysen har två frågor ställts till respektive tema: Vilka regler eller normer förekommer och dominerar? Vilka redskap tas i bruk? Analysen avser identifiera ledtrådar till elevernas mål för enskilda valhandlingar och tentativa objekt, som de riktar sina valhandlingar mot. Det vill säga, när målen för flera valhandlingar sammanfaller analytiskt kan vi dra slutsatser om elevernas objekt. Då datamängden är begränsad har vi valt benämningen elevernas tentativa objekt.

\section{Apl som skola}

Valhandlingar som karaktäriserar temat Apl som skola utför eleverna tillsammans med skolans yrkeslärare och/eller lärlingskoordinator, när de planerar för att genomföra sina yrkeskurser på arbetsplatser. Den regel som dominerar i det här sammanhanget är Skollagen (SFS 2010:800, 16 kap. 11 §), som föreskriver att lärlingsutbildningen till övervägande del ska genomföras som apl på en eller flera arbetsplatser. Närvaro på arbetsplatsen framstår som en regel från skolan. Exempel på andra regler och normer som styr från skolans sida är schemat, som reglerar vilka dagar varje vecka som eleverna är på sina arbetsplatser respektive i skolan.

På den aktuella skolan kan eleverna välja att byta arbetsplats flera gånger under sin utbildning. Skollagen (SFS 2010:800, 16 kap. 21-27 §§; SFS 2010:2039, 1 kap. 7 §) föreskriver också att varje elev ska ha en individuell studieplan. Studieplanen är ett dokument där skolan sammanställt vilka kurser som ingår i elevens utbildning. För de yrkeskurser som ingår i studieplanen behöver eleven således hitta en arbetsplats där motsvarande arbetsuppgifter genomförs de aktuella veckodagarna. Det är skolans ansvar att förmedla en arbetsplats som gör det möjligt för eleven att genomföra apl. I detta arbete framstår samtal med lärlingskoordinator och yrkeslärare i skolan som ett redskap som eleverna har till sitt förfogande för att välja arbetsplats. Dessa samtal utgår från kunskapsinnehåll i de yrkeskurser som ingår i studieplanen. Samtalen genomförs när nya kurser startar eller när eleverna byter från en arbetsplats till en annan. 
Ytterligare valhandlingar som karaktäriserar det här temat utför eleverna när de redovisar arbetsinnehåll som hör till kursmål. En dominerande regel är att eleverna förväntas kommunicera med yrkesläraren om sina arbetsuppgifter. Att skriva loggbok om arbetsuppgifterna kan ses som en regel, då flera yrkeslärare kräver att eleverna skriver varje vecka. Några elever säger att de skriver slentrianmässigt, medan andra säger att de skriver regelbundet. Beroende på hur eleverna använder loggboken kan den bli ett redskap, till exempel när de besvarar frågor som läraren skriver till dem. Ett annat eller alternativt redskap är samtal med yrkesläraren där eleverna redogör för sina prestationer på ett liknande sätt. Samtalen utspelar sig på lektioner i skolan och när läraren kommer på besök till arbetsplatsen. Den beskrivna elev-lärar-kommunikationen genomför eleverna med utgångspunkt $\mathrm{i}$ kunskapsinnehållet $\mathrm{i}$ de aktuella kursplanerna och sina egna prestationer på arbetsplatsen.

\section{Apl som arbete}

Valhandlingar som karaktäriserar temat Apl som arbete utför eleverna då de genomför förekommande arbetsuppgifter tillsammans med arbetsplatsens personal. Här är det arbetsplatsens regler och normer som styr vilka uppgifter eleven utför och vem eleven arbetar med. I exempelvis restauranger kan personalen ha oregelbundna arbetstider, medan eleven fortsatt har sina fasta tider varje vecka som i stället är anpassade efter skolans schema. Beroende på arbetsplats kan eleverna ha en eller flera handledare. En dominerande regel på arbetsplatserna är att det är arbetsplatsens personal som avgör hur arbetsuppgifterna ska utföras. De arbetsuppgifter eleven får tillgång till måste eleven således utföra på ett för den aktuella arbetsplatsen rätt sätt. Handledning av någon från arbetsplatsen framstår här som ett redskap som eleverna principiellt har till sitt förfogande på arbetsplatsen. Handledning sker exempelvis när eleverna frågar om arbetsuppgifter och tar del av handledarens instruktioner och demonstrationer. Den beskrivna elev-handledarinteraktionen utgår från produktionen och de arbetsuppgifter eleven får utföra under ett arbetspass.

Andra valhandlingar som karaktäriserar det här temat utför eleverna när de lär nytt $i$ arbete i samspel med handledaren och andra aktörer som exempelvis kunder/gäster. De regler som styr beror på relationen mellan eleven och handledaren. En dominerande regel på arbetsplatsen är att det är handledaren som tilldelar eleven nya arbetsuppgifter. En annan regel är att eleven efter en tid förväntas ta egna initiativ till nya arbetsuppgifter. Eleven kan antingen fråga efter en ny uppgift eller pröva att utföra ett nytt arbetsmoment på egen hand. Exempel på detta är när en elev tar sig an uppgiften att hjälpa kunder. Eleven använder produktinformation som finns på arbetsplatsens intranät för att förbereda sig för kundmötet. Under kundmötet tar eleven hjälp av handledaren för att besvara kundens frågor. Samtal med handledaren framstår som ett redskap som eleverna även tar i bruk för att lära sig nya arbetsuppgifter. Andra redskap är informa- 
tionsmaterial som finns på arbetsplatsen. Beroende på vilka redskap eleverna tar i bruk får de tillgång till olika kunskaper och färdigheter som behövs för att utföra arbetsuppgifterna. Det ovan beskrivna arbetsintegrerade utvecklandet av yrkeskunnande utför eleverna med utgångspunkt i pågående produktion och för dem helt eller delvis nya arbetsuppgifter.

\section{Apl som sammanförande av skola och arbete}

Valhandlingar som karaktäriserar temat Apl som sammanförande av skola och arbete utför eleverna när de identifierar arbetsuppgifter för skolan tillsammans med skolans yrkeslärare och arbetsplatsens handledare. Den dominerande regeln är att eleverna ska utföra arbetsuppgifter som svarar mot kunskapsinnehållet i deras respektive yrkeskurser. Varje elev ingår ett skriftligt avtal om apl med skolan och arbetsplatsen som regleras i Skollagen (SFS 2010:800, kap. 16 § 11 a). Vilka arbetsuppgifter eleven ska utföra behöver eleven således komma överens om med både skolans yrkeslärare och arbetsplatsens handledare. Trepartssamtal mellan eleven, yrkesläraren och handledaren framstår som en regel som skapats av skolan och som är yrkeslärarens uppgift att organisera. Trepartssamtalet kan också ses som ett redskap då även eleven är med och diskuterar de arbetsuppgifter hen ska lära sig på arbetsplatsen. Ett annat redskap är checklistor/matriser som ibland används av eleven, yrkesläraren och handledaren för att identifiera passande arbetsuppgifter. Det gemensamma arbetet med att utforma den enskilda elevens apl genomförs med utgångspunkt i elevens yrkeskurser och tillgängliga arbetsuppgifter.

Andra valhandlingar som karaktäriserar det här temat utför eleverna när de använder yrkesteori för arbete i skolan och på arbetsplatsen. Den dominerande regeln är att eleverna, när de har lektion i skolan, ska lära sig det innehåll i yrkeskurserna som inte är framträdande på arbetsplatsen. Exempel på detta är lagstiftning i arbetslivet. Dessa generella yrkeskunskaper som gäller oavsett arbetsplats behöver eleverna således bearbeta i skolan. I skoluppgifterna återknyter eleverna också till vad de ser, hör och gör på sina arbetsplatser. Denna typ av skoluppgifter kan ses som en regel då uppgifterna efterfrågas av yrkeslärarna. Ett exempel på denna regel är när eleverna på Restaurang- och livsmedelsprogrammet provsmakar drycker och jämför med utbud och användningsområde på arbetsplatserna. Den här typen av skoluppgifter indikerar också att olika inslag i arbetsplatsens produktion kan bli redskap som eleverna tar i bruk i skolan. Skoluppgifter framstår även som redskap som eleverna kan ta i bruk på sina arbetsplatser, exempelvis när elever som genomför apl i en restaurang tvättar händerna på det sätt som de lärt sig i skolan. Det här sammanförandet av generellt och arbetsplatsspecifikt yrkeskunnande utför eleverna med utgångspunkt i det kunskapsinnehåll som ingår i yrkesundervisningen och med utgångspunkt i vad som pågår på respektive arbetsplats. 


\section{Elevernas tentativa objekt}

Analysen av regler/normer och redskap ovan visar att eleverna genomför apl på arbetsplatser utifrån de val de genomfört i samråd med sin lärlingskoordinator och yrkeslärare. De förväntas utföra förekommande arbetsuppgifter och arbetsuppgifter som stämmer överens med kunskapsinnehållet i deras yrkeskurser. Yrkeskurserna har således en styrande funktion. Av samtalen med eleverna framgår emellertid att de har bytt arbetsplatser flera gånger, vilket indikerar att det finns spänningar och motsättningar mellan verksamhetssystemen skola och arbetsplats som eleverna behöver hantera. Principiellt ska eleverna genomföra planerade byten av arbetsplatser när en avtalad apl-period är slut. Eleverna initierar även byte när en arbetsplats inte motsvarar deras förväntningar, när de inte trivs med personalen eller när de inte får utföra överenskomna arbetsuppgifter. En del elever väljer att fullfölja en avtalad apl-period trots att arbetsplatsen inte till fullo motsvarar deras förväntningar. I det följande analyseras hur eleverna, genom sina valhandlingar, i relation till sådana situationer, är med och formar de tre identifierade tentativa objekten - betyg i skolans kurser, utveckling av yrkeskunnande och inkludering i arbetsplatsens gemenskap.

\section{Betyg i skolans kurser}

Eleverna utför flera valhandlingar som riktas mot att genomföra yrkeskurser på arbetsplatser, vilket indikerar att betyg i skolans kurser utgör ett möjligt tentativt objekt.

För att välja arbetsplats utgår eleverna från kunskapsinnehållet i de yrkeskurser som ingår i studieplanen. När arbetsuppgifterna inte motsvarar kunskapsinnehållet väljer några elever att säga till om missförhållandet, vilket resulterar i ändrade arbetsuppgifter eller byte av arbetsplats. Vid byte måste lärlingskoordinator hitta en ny plats som överensstämmer med elevens yrkeskurser. Andra elever väljer att vara kvar på arbetsplatsen som uppfyller kraven på arbetsuppgifter, men som för övrigt inte motsvarar dessa elevers förväntningar. Båda valhandlingarna kan förstås som handlingar som riktas mot att genomföra yrkeskurser på arbetsplatsen, vilket följande utsaga illustrerar:

\footnotetext{
M: Frukostpersonalen utnyttjade mig, de sa gör det och det. Min handledare bara gick och jag skulle ju sluta när [handledaren] slutade. De andra var ju trevliga, det var bara två i frukosten som var lite jobbiga. Intervjuaren: Frågade du om du fick byta?

M: Nej, jag har gått en termin på varje ställe så jag väntade. (M, Hotell och Turism)
}

Den här eleven väljer att fullfölja apl-perioden trots störningarna, att handledaren är frånvarande och att hen inte trivs med "två i frukosten". Elevens val indikerar att elevens avsikt är att genomföra arbetsuppgifter som ingår i yrkeskurserna som genomförs på arbetsplatsen. 
Eleverna redovisar också sina prestationer på arbetsplatsen i samtal med yrkesläraren och genom att skriva loggbok. En elev säger: "Jag skriver om kundbemötande och då kan läraren bocka av det. Utan loggbok blir det inget mål" (F, Handel och administration). Eleven pratar om kunskapskrav och mål som finns formulerade i yrkeskurserna. Att utföra bestämda arbetsuppgifter och skriva om dem i loggboken kan således förstås som valhandlingar som eleverna riktar mot att fullfölja yrkeskurser på arbetsplatsen.

Sammanfattningsvis indikerar elevernas valhandlingar att betyg i skolans kurser kan vara ett tentativt objekt. Eleverna kan välja att fullfölja en apl-period för att få utföra arbetsuppgifter som ingår i kurserna. De kan också välja att byta arbetsplats för att få tillgång till relevanta arbetsuppgifter. Andra deltagares handlingar som stöder antagandet om att objektet är betyg i skolans kurser, är lärlingskoordinators förmedling av arbetsplatser och yrkeslärarnas uppföljningar av elevernas prestationer. Även handlingar som utförs av handledare/ personal på arbetsplatser riktas mot samma tentativa objekt, det vill säga att eleverna handleds i arbetsuppgifter med motsvarande kunskapsinnehåll som i yrkeskurserna. Tillsammans bidrar dessa handlingar till att eleverna kan få betyg i skolans kurser och det möjliga utfallet - en gymnasial yrkesexamen. Betygen har i verksamhetsteoretisk mening ett bytesvärde och det är det som är det centrala för eleverna som utför dessa valhandlingar.

\section{Utveckling av yrkeskunnande}

Eleverna utför också valhandlingar som riktas mot att lära sig yrkesspecifika arbetsmoment, vilket indikerar att utveckling av yrkeskunnande är ett möjligt tentativt objekt.

För att få tillgång till yrkesspecifikt kunnande väljer eleverna att göra anspråk på nya arbetsuppgifter. Följande utsaga från en elev illustrerar detta:

\footnotetext{
A: Jag var på X-hotellet och gjorde salladsbuffé i fem månader. Jag frågade om att få vara i varmköket, men så blev det inte.

Intervjuaren: Vad gjorde du då?

A: Sa till lärarna och så fick jag byta till storköksrestaurangen. Och handledaren där är väldigt angelägen om att jag ska lära mig. Hen förklarar gärna och det är inget problem att fråga. Det här är lite av en prövotid tills de hittar något annat. Jag ska ju ha lite mer à la cartekök. Det vill lärarna och jag. (A, Restaurang och livsmedel)
}

Elevens intresse för ett specifikt kunnande styr valhandlingarna. Eleven frågar om hen får delta i "varmkök" och därefter om hen kan få byta arbetsplats. I samråd med yrkeslärare söker eleven en arbetsplats som bättre motsvarar elevens önskemål om kunskapsinnehållet i apl. " À la carte" som eleven vill lära sig handlar till skillnad från att prefabricera "salladsbuffé" eller maträtter i ett "storkök" om att tillaga rätter från en meny efter gästers beställning. Målet för elevens valhandlingar kan därför antas handla om att få tillgång till ett för kockyrket specifikt kunnande. I materialet finns också indikationer på att eleverna riktar sina 
handlingar mot yrkesspecifikt kunnande som finns inbäddat i arbetsprocesserna, till exempel att lära sig hjälpa kunder i butiken eller rekommendera dryck i restaurangen. Eleverna ställer frågor till sina handledare, tar initiativ till nya arbetsuppgifter, läser informationsmaterial och observerar hur andra arbetar. Eleverna tar också i bruk vad de lärt sig i skolan på arbetsplatsen, till exempel komponerar en elev en egen drink till gästen utifrån ett basrecept från skolan.

Sammanfattningsvis framstår utveckling av yrkeskunnande som ett tentativt objekt som är bundet till valhandlingar eleverna utför med utgångspunkt i det egna framväxande intresset för yrket. Antagandet om objektet stöds av handledare och yrkeslärare som riktar sina handlingar mot att eleverna ska få tillgång till arbetsuppgifter som möjliggör att de utvecklar önskat yrkeskunnande. I verksamhetsteoretisk mening kan formandet av det tentativa objektet, utveckling av yrkeskunnande, tolkas som att yrkeskunnandet har ett bruksvärde eller egenvärde för dessa elever.

\section{Inkludering i arbetsplatsens gemenskap}

Ytterligare ett mål som eleverna riktar sina valhandlingar mot handlar om att anpassa sig till arbetsplatsens produktion, vilket indikerar att inkludering i arbetsplatsens gemenskap är ett möjligt tentativt objekt.

Valhandlingar som riktas mot att anpassa sig till produktionen är till exempel när eleverna informerar sig om vad som händer på arbetsplatsen, tar emot och följer instruktioner, imiterar andra och tar initiativ till att utföra kända så väl som nya arbetsuppgifter genom att fråga eller pröva sig fram. Följande förklaring från en elev illustrerar hur dessa valhandlingar kommer till uttryck i det dagliga arbetet på en arbetsplats:

Jag läser menyn i förväg. Jag vet ju att salladen ska göras och den kan jag så jag har alltid ett hum om vad jag ska göra och jag kan alltid göra något. När jag kommer tidigt så går vi igenom det och när jag kommer senare så är det mer att jag hänger på, men [handledaren] förklarar ändà. (M, Restaurang och livsmedel)

Eleven anpassar sig till produktionen genom att utföra de dagliga rutinuppgifterna som "salladen" och genom att "hänga på", det vill säga följa instruktioner och imitera andra. Målet med valhandlingarna kan därför antas vara att utföra de förekommande arbetsuppgifterna på rätt sätt, för att uppnå avsett resultat i pågående produktion. Förekommande arbetsuppgifter stämmer inte alltid överens med kunskapsinnehållet i elevernas yrkeskurser. Ett exempel på detta är en elev som vid sidan av sina arbetsuppgifter i hotellets reception och våningsservice också arbetar i köket. Yrkesläraren undersöker om det finns kurser i matlagning som stämmer överens med elevens arbetsuppgifter och som kan läggas in i elevens studieplan. Det gör det inte, men eleven fortsätter ändå att utföra arbetsuppgifterna i köket. Eleverna ger också uttryck för att de kan erbjudas någon form av anställning när de behärskar förekommande arbetsuppgifter. 
Sammanfattningsvis indikerar elevernas valhandlingar som riktas mot att anpassa sig till arbetsplatsens produktion att inkludering i arbetsplatsens gemenskap kan vara ett tentativt objekt. Andra handlingar som stöder antagandet om objektet är när handledarna tilldelar eleverna arbetsuppgifter som måste utföras under pågående produktion, och när yrkesläraren med utgångspunkt i elevens arbetsuppgifter försöker lägga in andra yrkeskurser i elevens studieplan. Även i detta fall kan elevernas objekt beskrivas i termer av bytesvärde, men av annan karaktär än ovan där bytesvärdet är betyget. Genom att eleverna anpassar sig kan deras deltagande få ett värde för produktionen. För dessa elever är bytesvärdet att inkluderas i arbetsplatsens gemenskap, vilket kan leda till exempelvis ett sommarjobb.

\section{Diskussion och konklusion}

Den här artikeln sammanfattar en fallstudie som med verksamhetsteoretiska utgångspunkter undersökt hur elever som genomför en svensk gymnasial lärlingsutbildning bidrar till att forma de objekt de kan ha för sin yrkesutbildning, i samband med apl. Artikeln bidrar med kunskap om hur elevers valfrihet och inflytande, som sedan länge betonats i gymnasieskolans läroplaner (1970), kommer till uttryck genom de valhandlingar eleverna utför tillsammans med andra som finns i skolan och på deras apl-arbetsplatser. Till skillnad från Lund (2006) och Rosvall (2012) som visat hur elever genom olika valhandlingar påverkar vilket kunskapsinnehåll som manifestas i deras utbildning, visar föreliggande studie på mer explicita valhandlingar som eleverna utför, och hur dessa val får konsekvenser för vad eleverna lär sig och för deras studieresultat.

I resultatanalysen som redovisas ovan framträder tre tentativa objekt som eleverna kan ha som överordnade och underordnade under en apl-period - betyg i skolans kurser, utveckling av yrkeskunnande och inkludering i arbetsplatsens gemenskap. Elever som har betyg i skolans kurser som sitt överordnade objekt tenderar att prioritera arbetsuppgifter som ingår i yrkeskurserna, samt att redovisa dessa för yrkesläraren. Elever som har utveckling av yrkeskunnande som sitt överordnade objekt tenderar i stället att prioritera arbetsplatser och arbetsuppgifter som ger tillgång till det yrkeskunnande de själva önskar utveckla. Elever som har inkludering i gemenskapen på arbetsplatsen som överordnat objekt prioriterar arbetsuppgifter som bidrar till produktionen på den aktuella arbetsplatsen. Anmärkningsvärt är att objektet inte verkar vara statiskt utan eleverna kan prioritera ett objekt under en period för att sedan prioritera ett annat. Beroende på vilket objekt eleverna har som överordnat respektive underordnat under en apl-period framträder också två slags bytesvärden som yrkesutbildningen kan ha för eleverna. Å ena sidan kan kursbetyg resultera i en gymnasieexamen, å andra sidan kan inkludering $i$ arbetsplatsens gemenskap resultera i en anställ- 
ning. För eleverna utesluter det ena objektet inte nödvändigtvis det andra. I verksamhetsteoretisk mening finns det emellertid alltid ett motiv som ligger till grund för objektet. Enligt Engeström (2001) är komplexa verksamheter multimotivdrivna. Han menar att skolan är ett sådant exempel, vilket också betyder att eleverna som deltar i denna verksamhet kan utveckla flera motiv för deltagande. Yrkesutbildning som sker i samverkan mellan skola och arbetsplatser kan bidra till att eleverna utvecklar nya motiv för sitt deltagande under sin utbildning.

I likhet med andra studier som undersökt elevers agens och utveckling av yrkeskunnande (ex. Kristmansson, 2016; Rintala \& Nokelainen, 2020) visar vår studie hur eleverna får tillgång till yrkeskunnande genom att anpassa sina handlingar till vad som pågår på den aktuella arbetsplatsen. Eleverna följer exempelvis instruktioner, frågar sig fram och tar initiativ till att utföra förekommande arbetsuppgifter. Dessa valhandlingar är i linje med vad Ferm m.fl. (2018) identifierat som lärstrategier som elever använder för att styra sitt eget lärande på arbetsplatsen. Valhandlingarna framstår därigenom även som väsentliga för vilket yrkeskunnande eleverna kan utveckla i samband med apl, det vill säga yrkeskunnande som explicitgörs när eleverna genomför apl i yrkesutbildningen. Exempel på yrkeskunnande som identifieras i den här studien är produkt- och materialkunskap, färdigheter i att utföra vanliga arbetsuppgifter, samt förmåga att ta egna initiativ och kommunicera om arbetsuppgifters utförande.

Elevernas kommunikation med skolans yrkeslärare och arbetsplatsens handledare visar sig vara betydelsefull, både för vilket yrkeskunnande eleverna får tillgång till och för deras studieresultat. Tidigare studier visar huvudsakligen hur kommunikationen styrs av yrkeslärare eller handledare (ex. Sandal m.fl., 2014; Wyszynska Johansson, 2021), medan det i denna studie finns flera exempel på hur eleverna bidrar till kommunikationen genom loggboksskrivande, samtal med yrkesläraren, samtal med handledare på arbetsplatser och i trepartssamtal. Att eleverna kommunicerar på flera olika sätt, med olika redskap, antyder att eleverna, yrkesläraren och handledaren på arbetsplatsen kan ha olika förväntningar på vilka uppgifter eleverna ska utföra och vad de ska lära sig på arbetsplatsen (jmf. Nielsen m.fl., 2021; Sappa m.fl., 2016).

Den verksamhetsteoretiska analysen har synliggjort elevernas valhandlingar och vilket yrkeskunnande de kan få tillgång till i förhållande till regler/normer som finns inbäddade i den aktuella skolans och de medverkande arbetsplatsernas verksamhetssystem (jmf. Berner, 2010; Kilbrink m.fl., 2018; Virtanen m.fl., 2014). I analysen ges flera exempel på hur elever i samspel med skolans lärlingskoordinator och yrkeslärare både väljer och byter arbetsplatser för att få tillgång till arbetsuppgifter som kan ingå i deras utbildning, och som kan bidra till att de utvecklar avsett eller önskat yrkeskunnande. En del elever nöjer sig med det yrkeskunnande som de får tillgång till under förutsättning att det resulterar i god- 
känt betyg och/eller en framtida anställning. För de elever vars objekt är inkludering $\mathrm{i}$ arbetsplatsens gemenskap handlar yrkeskunnandet om att anpassa sig till vad som är rätt på den aktuella arbetsplatsen. Elever som kommit att intressera sig för en specifik aspekt av yrkeskunnande, som inte blir tillgänglig på en arbetsplats, kan hantera svårigheten genom att tillsammans med skolans lärlingskoordinator och yrkeslärare hitta en ny arbetsplats som motsvarar förväntningarna. För dessa elever, där yrkeskunnandet i sig är objektet, kan det handla om att bredda eller fördjupa sitt yrkeskunnande i förhållande till något yrkesspecifikt. Yrkeskunnandet får därmed ett bruksvärde för eleverna som själva funnit ut vad de vill lära sig på arbetsplatsen. Att yrkesutbildningen handlar om både skola och arbete för eleverna blir också tydligt då bytesvärdet inte enbart visar sig vara betyg, det kan lika gärna vara en anställning. Att apl i yrkesutbildningen kan ha olika bruks- och bytesvärde för eleverna indikerar att yrkesutbildningen som eleverna genomför också motsvarar skilda politiska intentioner och förväntningar som kan finnas i arbetslivet (se Andersson m.fl., 2015; Olofsson \& Persson Thunqvist, 2018). Yrkesutbildningen som de här lärlingseleverna genomför kan således resultera i utbildningsvägar som svarar mot flera olika motiv.

Baserat på studiens resultat och diskussionen ovan är slutsatsen att framför allt elevernas, men även andra deltagares, förväntningar behöver tydliggöras där utbildning pågår. Det handlar om att samarbeta över gränser mellan verksamhetssystem, samt att löpande kommunicera vad varje elev förväntas lära sig på arbetsplatsen och vilka arbetsuppgifter eleven kan medverka i. Det handlar också om att synliggöra vad de uppgifter som eleven utför, i skolan och på arbetsplatsen, har för betydelse i arbetsplatsens produktion och för eleverna i yrkesutbildningen.

\section{Om författarna}

Ingela Andersson är doktorand och arbetar som universitetsadjunkt vid Göteborgs universitet, Institutionen för pedagogik och specialpedagogik. Hon undervisar och föreläser i kurser på yrkeslärarprogrammet och personalvetarprogrammet. Hennes forskningsintressen är formering av yrkesutbildning, yrkeskunnande, gränsöverskridande arbete och arbetsplatsbaserat lärande. Avhandlingen handlar om hur gymnasial lärlingsutbildning tar form inom och mellan skola och arbetsliv.

Viveca Lindberg är docent i komparativ ämnesdidaktik vid Stockholms universitet, Institutionen för ämnesdidaktik. Hennes forskningsintressen är yrkeskunnande och lärande inom yrkes- och professionsutbildningar, med specifikt intresse för uppgifter och bedömning av yrkeskunnande samt yrkes-/professionsrelaterat skriftbruk. 


\section{Referenser}

Aakernes, N. (2017). From school to work: Coherence between learning in school and learning in workplaces for apprentices in the Media graphics programme in Norway. Nordic Journal of Vocational Education and Training, 8(1), 76-97. https://doi.org/10.3384/njvet.2242-458X.188176

Akkerman, S. \& Bakker, A. (2012). Crossing boundaries between school and work during apprenticeships. Vocations and Learning, 5(2), 153-173.

https:/ / doi.org/10.1007/s12186-011-9073-6

Andersson, I. (2018). Workplace learning for school-based apprenticeships: Tripartite conversations as a boundary-crossing tool. I S. Choy, G-B. Wärvik \& V. Lindberg (Red.), Integration of vocational education and training experiences: Purposes, practices and principles (s. 259-278). Springer.

https:/ / doi.org/10.1007/978-981-10-8857-5_14

Andersson, I., Wärvik, G-B. \& Thång, P-O. (2015). Formation of apprenticeships in the Swedish education system: Different stakeholder perspectives. International Journal for Research in Vocational Education and Training, 2(1), 1-24.

https:/ / doi.org/10.13152/IJRVET.2.1.1

Aspøy, T. \& Nyen, T. (2017). Short-term benefits, long-term harm? Alternative training to apprenticeships in Norway. International Journal for Research in $V^{-}$ cational Education and Training, 4(4), 306-324.

https:/ / doi.org/10.13152/IJRVET.4.4.1

Baartman, L., Kilbrink, N. \& De Bruijn, E. (2018). VET students' integration of knowledge engaged with in school-based and workplace-based learning environments in the Netherlands. Journal of Education and Work, 31(2), 204-217. https:/ / doi.org/10.1080/13639080.2018.1433821

Berglund, I. (2009). Byggarbetsplatsen som skola - eller skolan som byggarbetsplats? En studie av byggnadsarbetares yrkesutbildning. [Doktorsavhandling, Stockholms universitet].

Berglund, I., Höjlund, G., Kristmansson, P. \& Paul, E. (2017). Gymnasial lärlingsutbildning ur ett pedagogiskt och didaktiskt perspektiv - med utgångspunkt i försöksverksamheten 2008-2014 (RIPS, Rapporter från institutionen för pedagogik och specialpedagogik, nr 13). Göteborgs universitet.

Berglund, I., Lumsden Wass, K. \& Wärvik, G-B. (2016). Samverkan mellan skolan och det lokala arbetslivet inom gymnasial lärlingsutbildning-organisatoriska och didaktiska modeller. Göteborgs universitet, Institutionen för pedagogik och specialpedagogik. https://cms.it.gu.se/infoglueDeliverWorking/digitalAssets/1588/1588318_rapport-skolverkstudie-ht-2015---slutversion-160312.pdf

Berner, B. (2010). Crossing boundaries and maintaining differences between school and industry: Forms of boundary-work in Swedish vocational education. Journal of Education and Work, 23(1), 27-42.

https:/ / doi.org/10.1080/13639080903461865 
Billett, S. (2016). Apprenticeship as a mode of learning and model of education. Education \& Training, 58(6), 613-28. https:/ / doi.org/10.1108/ET-01-2016-0001

Billett, S., Wärvik, G-B. \& Choy, S. (2018). Concepts, purposes and practices across national curriculum. I S. Choy, G-B. Wärvik \& V. Lindberg (Red.), Integration of vocational education and training experiences: Purposes, practices and principles (s. 327-344). Springer.

https:/ / doi.org/10.1007/978-981-10-8857-5_17

Bäckman, O., Jakobsen, V., Lorentzen, T., Österback, E. \& Dahl, E. (2011). Dropping out in Scandinavia: Social exclusion and labour market attachment among upper secondary school dropouts in Denmark, Finland, Norway and Sweden (Arbetsrapport 2011:8). Institutet för Framtidsstudier.

Engeström, Y. (2001). Expansive learning at work: Toward an activity theoretical reconceptualization. Journal of Education and Work, 14(1), 133-156. https:/ / doi.org/10.1080/13639080020028747

Engeström, Y. \& Sannino, A. (2011). Discursive manifestations of contradictions in organizational change efforts: A methodological framework. Journal of Organizational Change Management, 24(3), 368-387. https:/ / doi.org/10.1108/09534811111132758

Ferm, L. (2021). Vocational students' agency in identity formation as industrial workers. [Doktorsavhandling, Linköpings universitet].

https://www.diva-portal.org/smash/get/diva2:1546899/FULLTEXT01.pdf

Ferm, L., Persson Thunqvist, D., Svensson, L. \& Gustavsson, M. (2018). Students' strategies for learning identities as industrial workers in a Swedish upper secondary school VET programme. Journal of Vocational Education E Training, 70(1), 66-84. https:/ / doi.org/10.1080/13636820.2017.1394357

Fjellström, M. (2017). Becoming a construction worker: A study of vocational learning in school and work life. [Doktorsavhandling, Umeå universitet]. http://umu.diva-portal.org/smash/get/diva2:1078398/FULLTEXT03.pdf

Forsberg, E. (2011). What is the logic of an interest-based curriculum? I E. Forsberg (Red.), Curriculum theory revisited: Curriculum as content, pedagogy and evaluation (s. 109-121). Lambert Academic Publishing.

Fuller, A. \& Unwin, L. (2011). Apprenticeship as an evolving model of learning. Journal of Vocational Education E Training, 63(3), 261-266. https://doi.org/10.1080/13636820.2011.602220

Garmannslund. E. \& Witsø, H. (2016). Lærings- og arbeidsvaner hos lærlinger. Nordic Journal of Vocational Education and Training, 6(1), 23-41. https:/ / doi.org/10.3384/njvet.2242-458X.177123

Graneheim, U. \& Lundman, B. (2004). Qualitative content analysis in nursing research: Concepts, procedures and measures to achieve trustworthiness. Nurse Education Today, 24(2), 105-112. https://doi.org/10.1016/j.nedt.2003.10.001 
Griffiths, T. \& Guile, D. (2003). A connective model of learning: The implications for work process knowledge. European Educational Research Journal, 2(1), 56-73. https:/ / doi.org/10.2304/eerj.2003.2.1.10

Gåfvels, C. (2016). Skolad blick på blommor: Formandet av yrkeskunnande i floristutbildning. [Doktorsavhandling, Stockholms universitet]. http://su.diva-portal.org/smash/get/diva2:953521/FULLTEXT01.pdf

Jonasson, C. (2014). Defining boundaries between school and work: Teachers and students' attribution of quality to school-based vocational training. Journal of Education and Work, 27(5), 544-563. https:/ / doi.org/10.1080/13639080.2013.787483

Kilbrink, N., Bjurulf, V., Baartman, L. \& Bruijn, E. (2018). Transfer of learning in Swedish technical vocational education: Student experiences in the energy and industry programmes. Journal of Vocational Education $\mathcal{E}$ Training, 70(3), 455475. https://doi.org/10.1080/13636820.2018.1437064

Kristmansson, P. (2016). Gymnasial lärlingsutbildning på Handels- och administrationsprogrammet: En studie av lärlingsutbildningens förutsättningar och utvecklingen av yrkeskunnande. [Doktorsavhandling, Umeå universitet]. http://www.diva-portal.org/smash/get/diva2:1040061/FULLTEXT01.pdf

Lindberg, V. (2003). Yrkesutbildning i omvandling: En studie av lärandepraktiker och kunskapstransformationer. [Doktorsavhandling, Stockholms universitet].

http://www.diva-portal.org/smash/get/diva2:225794/FULLTEXT01.pdf

Lund, S. (2006). Marknad och medborgare: Elevers valhandlingar i gymnasieutbildningens integrations- och differentieringsprocesser. [Doktorsavhandling, Växjö universitet].

http://www.diva-portal.org/smash/get/diva2:206731/FULLTEXT01.pdf

Lundahl, L., Arreman, I. E., Lundström, U. \& Rönnberg, L. (2010). Setting things right? Swedish upper secondary school reform in a 40-year perspective. European Journal of Education, 45(1), 46-59.

https:/ / doi.org/10.1111/j.1465-3435.2009.01414.x

Miettinen, R. (1999). Transcending traditional school learning: Teachers' work and networks of learning. I Y. Engeström, R. Miettinen \& R-L. Punamäki (Red.), Perspectives on activity theory. Learning in doing: Social, cognitive, and computational perspectives (s. 325-344). Cambridge University Press.

Mårtensson, Å. (2014). Handledare och handledning: Gymnasial yrkesutbildning på förskola. [Licentiatuppsats, Linköpings universitet]. http://liu.diva-portal.org/smash/get/diva2:766291/FULLTEXT01.pdf

Nielsen, K. T. P., Louw, A. \& Katznelson, N. (2021). Plads til at lære - på lærepladsen: Dannelse $i$ mødet mellem unge og arbejdsmarkedet (1 utg.) (Ungdomsliv Nr. 11). Aalborg Universitetsforlag.

Nardi, B. (1996). Studying context: A comparison of activity theory, situated action models and distributed cognition. I B. Nardi (Red.), Context and consciousness: Activity theory and human-computer interaction. MIT Press. 
Nore, H. \& Lahn, L. C. (2014). Bridging the gap between work and education in vocational education and training: A study of Norwegian apprenticeship training offices and e-portfolio systems. International Journal for Research in Vocational Education and Training, 1(1), 21-33.

https:/ / doi.org/10.13152/IJRVET.1.1.2

Olofsson, J. \& Persson Thunqvist, D. (2018). The modern evolution of VET in Sweden (1945-2015). I S. Michelsen \& M-L. Stenström (Red.), Vocational education in the Nordic countries: The historical evolution (s. 124-145). Routledge.

Paul, E. (2017). Skriftbruk som yrkeskunnande i gymnasial lärlingsutbildning: Vårdoch omsorgselevers möte med det arbetsplatsförlagda lärandets skriftpraktiker. [Doktorsavhandling, Stockholms universitet]. http:/ / su.diva-portal.org/smash/get/diva2:1129071/FULLTEXT01.pdf

Prop. 1990/91:85. Växa med kunskaper: Om gymnasieskolan och vuxenutbildningen. Regeringen. https:/ / data.riksdagen.se/fil/D0456AD9-B657-459E-A056-A05CC9D2809B

Reegård, K. (2020). Når lærlingen møter arbeidslivets vurderingslogikk: Yrkessosialisering i det norske salgsfaget. Nordic Journal of Vocational Education and Training, 10(3), 67-82. https:/ / doi.org/10.3384/njvet.2242-458X.2010367

Rosvall, P-Å. (2012). "... det vore bättre om man kunde vara med och bestämma hur det skulle göras...": En etnografisk studie om elevinflytande i gymnasieskolan. [Doktorsavhandling, Umeå universitet].

https:/ / www.diva-portal.org/smash/get/diva2:877023/FULLTEXT01.pdf

Rintala, H. \& Nokelainen, P. (2020). Vocational education and learners' experienced workplace curriculum. Vocations and Learning, 13(1), 113-130. https:/ / doi.org/10.1007/s12186-019-09229-w

Sandal, A. K., Smith, K. \& Wangensteen, R. (2014). Vocational students experiences with assessment in workplace learning. Vocations and Learning, 7(2), 241261. https://doi.org/10.1007/s12186-014-9114-z

Sappa, V. \& Aprea, C. (2014). Conceptions of connectivity: How Swiss teachers, trainers and apprentices perceive vocational learning and teaching across different learning sites. Vocations and Learning, 7(3), 263-287. https:/ / doi.org/10.1007/s12186-014-9115-y

Sappa, V., Choy, S. \& Aprea, C. (2016). Stakeholders' conceptions of connecting learning at different sites in two national VET systems. Journal of Vocational Education \& Training, 68(3), 283-301. https://doi.org/10.1080/13636820.2016.1201845

Schaap, H., Baartmaan, L. \& Bruijn, E. (2012). Students' learning processes during school-based learning and workplace learning in vocational education: A review. Vocations and Learning, 5(2), 99-117.

https:/ / doi.org/10.1007/s12186-011-9069-2

SFS 2010:800. Skollag. http:/ / www.riksdagen.se/sv/DokumentLagar/Lagar/Svenskforfattningssamling/Skollag-2010800_sfs-2010-800/ 
SFS 2010:2039. Gymnasieförordning. https:/ / www.riksdagen.se/sv/dokument-lagar/dokument/svensk-forfattningssamling/gymnasieforordning-20102039_sfs-2010-2039

Skolöverstyrelsen. (1971). Läroplan för gymnasieskolan, Lgy 70. 1. Allmän del. Liber Utbildningsförlaget.

SOU 1997:107. Den nya gymnasieskolan: Problem och möjligheter. https:/ / www.regeringen.se/49b723/contentassets/563315a907c64978acd3e9db8b74d85a/ sou-1997107

Stetsenko, A. (2005). Activity as object-related: Resolving the dichotomy of individual and collective planes of activity. Mind, Culture and Activity, 12(1), 7088. https://doi.org/10.1207/s15327884mca1201_6

Tuomi-Gröhn, T., Engeström, Y. \& Young, M. (2003). From transfer to boundarycrossing between school and work as a tool for developing vocational education: An introduction. I T. Tuomi-Gröhn \& Y. Engeström (Red.), Between school and work: New perspectives on transfer and boundary-crossing (s. 1-18). Pergamon.

Vetenskapsrådet. (2011). God forskningssed. Vetenskapsrådet.

Virtanen, A., Tynjälä, P. \& Eteläpelto, A. (2014). Factors promoting vocational students' learning at work: Study on student experiences. Journal of Education and Work, 27(1), 43-70. https:/ / doi.org/10.1080/13639080.2012.718748

Wenger, E. (1998). Communities of practice: Learning, meaning, and identity. Cambridge University Press.

Wyszynska Johansson, M. (2021). "Du har skött dig bra": Återkoppling inom arbetsplatsförlagt lärande utifrån yrkeselevers upplevda läroplan. Nordic Journal of Vocational Education and Training, 10(3), 99-121. https:/ / doi.org/10.3384/njvet.2242-458X.2010399

Yin, R. (2018). Case study research and applications: Design and methods (6 utg.). Sage. 